\title{
Working capital management and performance in manufacturing sector of Pakistan
}

\author{
Muhammad Mahmood Shah Khan \\ Rubeena Tashfeen \\ School of Business and Economics \\ University of Management and Technology, Lahore, Pakistan \\ Sumbal Saghir \\ Institute of Research Promotion, Lahore, Pakistan
}

\section{Keywords}

Working capital, Inventory turnover in days, Average collection/payment period, Cash conversion cycle, Gross operating profitability

\begin{abstract}
Purpose: The main objective of the study is to examine whether there is an effective management over components of working capital in the manufacturing sector of Pakistan.

Design/Methodology: Data is collected from the annual reports of 94 Pakistani non-financial firms listed on Pakistan Stock Exchange (PSX) for the period of 2011- 2016. Fixed Effects methodology is employed in the study after determining the best fit model through the Hausman test, and effectiveness of working capital management is gauged through the impacts on profitability of the firm.

Findings: The results show that inventory turnover, average collection period and cash conversion cycle have an insignificant relationship with profitability, indicating that working capital management (WCM) is not important in the manufacturing sector. It appears levels of current assets are maintained to support current ratio and solvency to sustain the high levels of debt financing. However, average payment period has a significant negative association with profitability demonstrating that firms may be managing working capital through payables, where reduction in payables increase profitability through better trade and cash discounts and timely supplies. Therefore, it is evidenced that management focuses on the liabilities side of the WCM equation and maintains current assets for other purposes.

Practical implication: The results provide insights into manufacturing sector practice of maintaining levels of current assets as cushion against financial and operational risks, and the managing of working capital requirements through payables. It provides banks and other financial institutions a perspective into the working capital behavior of the manufacturing sector.

Originality statement: The paper provides innovative insights into the manufacturing sector practice of focusing on the current liabilities to manage working capital and maintaining levels of current assets as cushion against risk and to support borrowings. It suggests that in this sector, the conventional working capital practices are not applied.
\end{abstract}

Corresponding author: Muhammad Mahmood Shah Khan

Email addresses for the corresponding author: mahmoodshah@umt.edu.pk

First submission received: $15^{\text {th }}$ April 2018

Revised submission received: $11^{\text {th }}$ June 2018

Accepted: 15 th August 2018

\section{Introduction}

The manufacturing sector is the second largest business sector and plays a major role in the economic growth of the country. In 2016, the manufacturing sector contributed $13.6 \%$ to the Gross Domestic Product (GDP) of Pakistan. This sector includes companies such as: automobile assembler, automobile parts and accessories; cable and electrical goods; cement; chemical; engineering; fertilizer; food and personal care products; glass and ceramics; leather and tanneries; sugar; pharmaceutical; oil and 
gas; and textile and woolen companies, among others. In the past, the manufacturing sector was not performing well due to internal and external obstacles like energy crises, political instability and slow global economic growth. According to the government of Pakistan Ministry of Finance (Pakistan Economic Survey, 2015-2016), government has taken several steps to boost the manufacturing sector through the China-Pakistan Economic Corridor (CPEC) initiative to primarily resolve the energy crisis, among others.

In this scenario of growth and expansion under CPEC, it is imperative that firms utilize their resources optimally in order to compete with other foreign companies entering the Pakistani markets. Lower costs and higher quality products will determine the competitiveness and survival of local companies. Therefore, alongside better monitoring of long-term assets and financing, the effective management of working capital and short-term resources is crucial. Working capital is like the life line of any organization and a low or excess capacity may become dangerous for survival of the firm (Ponsian, Chrispina, Tago and Mkiibi, 2014).

Working capital could have both a positive or negative impact on profitability of the firm. If a firm has excess and idle current assets, it would have a negative impact on profits. At the same time scarcity of current assets would reduce revenues and lead to the bankruptcy (Horne and Wachowicz, 2004). Working capital management has a direct impact on liquidity and profitability and by adopting good practices, firms can achieve a balance between profitability and liquidity (Rizwan and Shah, 2015).

The proper management of working capital translates into the optimal utilization and control of its components: accounts receivables, accounts payables, inventory and the cash conversion cycle. All the components are linked with profitability because their high or low quantity may affect the profit earning capacity of firms. In the control over receivables, management focuses on efficient management of credit policy. Problems arise when debtors do not pay their debt on time. However, when trying to improve sales credit policies, managers also need to be aware of the impacts on profits and associated costs (Nasreen, Khanam and Pirzada, 2014).

While managing accounts payables, firms adopt different measures to make payments optimally. Firms may employ either of two approaches: contraction or expansion approach. In the contraction approach, firms focus on the cost of trade. In expansion mode, firms try to avail maximum benefit of funds in maximum time. Both approaches provide benefits to the company. While inventory management tantamount to firms striving to maintain optimal inventory with the objective to increase inventory turnover and lower the financial costs resulting in an increase in profitability (Kumaraswamy, 2016).

The most important component of working capital management is cash conversion cycle and it is associated with the other three components: inventory, receivables and payables. Cash conversion cycle is basically the time frame between the purchase of goods and the collection of cash against it from customers. The time span of cash conversion cycle increases with increase in inventory and receivable collection period and reduces the profitability of firms. There should be negative relationship between cash conversion cycle and profitability as a lower cash conversion cycle would benefit firms (Raza, Bashir, Latif, Shah and Ahmad,2015).

The manufacturing sector largely contributes to growth and economic development of Pakistan and is continuously moving towards more efficiency and improvement. We are interested to examine whether this sector is managing their working capital efficiently and to learn from their short-term resources management behavior.

\section{Problem Statement and Research Objectives}

Extant research in Pakistan has examined the relationship of working capital management and profitability. Generally, results show existing deficiencies related to the weak management of operating cycles due to some internal factors. Main issues show inefficient management of the components of working capital like inventory control issues, irrecoverable debts and hurdles while making payments to customers (Mathuva, 2010; Nazir and Afza, 2009; Raheman and Nasr, 2007). However, there is a lack of consensus in the findings and we segregate the manufacturing sector for our examination of effectiveness of working capital management and its impact on profitability. 
Therefore, the main objective of the study is to examine the impact of working capital management on profitability of non-financial firms in Pakistan. This leads to the sub-objectives: to analyze the impact of inventory management on profitability; to investigate the impact of receivable collection management on profitability; to determine the effect of accounts payable management on the profitability; and to identify the impact of cash conversion cycle on the profitability.

\section{Research Methodology, and Sample Data}

Towards achievement of our research objectives, we use correlational and ex-post facto approaches. In ex-post facto research design, we examine the impact of the working capital management on firm profitability, while in the correlation design the degree of association between dependent and independent variables has been analyzed.

The sample comprises secondary data taken from financial statements of firms listed on the Pakistan Stock Exchange. As all data is not available online, therefore to a large extent the required information has been collected manually from financial statements. The final data sample comprises 94 non-financial firms, over a six-year period from 2011-2016 to a total of 564 firm year observations.

As depicted in Table 1, the data consists of all non-financial sectors excluding financial, banking and information technology businesses. Of a total of 35 sectors listed on the PSE-100 Index, a total of 23 industrial sectors have been covered in the study.

\begin{tabular}{|l|l|}
\hline Sectors listed in PSE & 35 \\
\hline Less: Financial and Other service sectors & -11 \\
\hline Non-Financial Sectors & 24 \\
\hline Less: Non-financial Sector missing information & -1 \\
\hline Remaining Non-Financial Sectors & 23 \\
\hline
\end{tabular}

Table 1: Criteria for the Selection of Sectors

From a population of 24 non-financial business sectors, we have taken the 5 companies of each sector according to the highest revenue in year 2016. Details are provided in Table 2, and the sample companies are listed out in Appendix 1.

\begin{tabular}{|l|l|}
\hline Top 5 companies of each sector $(23 * 5)$ & 115 \\
\hline Less: Companies missing data 2011-2016 & -26 \\
\hline Sample consist of Companies & 94 \\
\hline
\end{tabular}

Table 2: Criteria for the Selection of Companies

The data is constructed as cross-sectional and time series dimensions so that it is considered as panel data. All the hypothesis models are tested by using panel data methodology. Analysis is conducted using EViews 9.0 version and tests are conducted to perform: statistical descriptive analysis; correlation analysis; and multiple linear regression.

The regression methodology is selected on the basis of following models: fixed effects model; random effects model and the Hausman test is applied to choose most appropriate model for analysis. Robustness checks are applied to ensure the validity and fitness of model. Serial correlation of data are tested through the Durbin Watson tests and multicollinearity is checked through the Variance Inflation Factor (VIF), where ideally the VIF value should be less than 10 to exclude problems of multicollinearity.

\section{Theoretical Framework}

Working capital alludes to the financing that a firm requires to finance operations and shows whether sufficient funds are available to pay current debts and operational expenditure. Thus, working capital management includes the management of inventories, trade receivables, trade payables and cash. In our study, we choose these specific variables in the manner of researchers (Deloof, 2003; Garcia-Teruel 
and Martinez-Solano, 2007; Jose, Lancaster and Stevens, 1996; Nazir and Afza, 2009; Raheman and Nasr, 2007; Shin and Soenen, 1998) who use these variables in their investigation of the relationship between working capital management and profitability.

Thus, Working Capital indicates the current assets that are required for operations, while Net Working Capital is current assets minus current liabilities, and indicates the short-term capital that would be required to support current assets needed for operations. Figure 1 presents the framework of the study and the hypotheses are explained under Section 2.3. While the variable definitions are provided in Table 3, given below

\section{Variable Measurement}

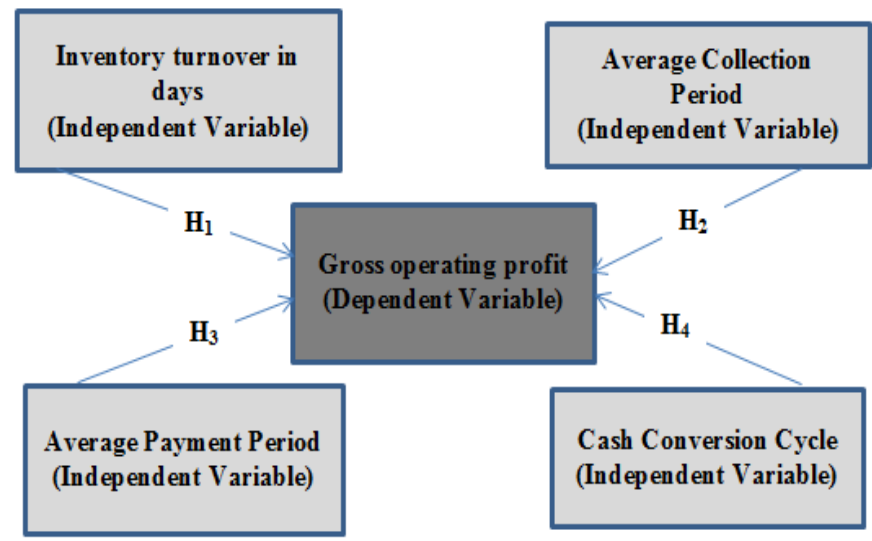

Working capital is taken as current assets less current liabilities where current assets comprise inventories and accounts receivables, while current liabilities are accounts or trade payables such as:

Net Working Capital $=$ Current Assets - Current Liabilities....

And current asset management may be achieved through the management of inventory turnover and average receivables collection period. While current liabilities management entails monitoring of the average accounts payables period. The relationship may also be depicted through the cash conversion cycle where the quick recovery of cash indicates efficient management of short-term operations. Therefore, the cash conversion cycle may be stated as:

Cash Conversion Cycle = Inventory conversion period + Receivables collection period-Payables deferral period... (2). The Cash Conversion Cycle Model and the relationship between the various working capital components are presented in Figure 2 (from Brigham and Ehrhardt, 2002, pp. 844, fig. 22-2). 




Figure 2 The Cash Conversion Cycle Model

Source: Brigham and Ehrhartdt (2002)

The above model indicates that ceteris paribus, a faster inventory turnover and quicker collection of receivables along with longer deferral of payment of payables would reduce the time from buying raw material (outflow of cash) to the selling of products and collecting cash on sales (inflow of cash).

\section{Independent Variables}

The particular set of independent variables have been popularly used in the literature to capture the impacts of working capital and its components. However, there are mixed results in respect of the impacts of working capital management on firm profitability. Some studies indicate that there exists a negative relation of all components of working capital leading to an increase in the profitability and vice versa that a positive relation of different components of working capital leads to decrease the profitability of firms as whole. All the variable descriptions are provided in Table 3.

The first independent variable is Inventory turnover in days (ITID), and it represents the number of days required to convert the raw material into finished goods or to hold the inventory before sale and is measured as: ITID = Inventory * 365 / Cost of goods sold. The second independent variable is Average collection period (ACP) and it represents the span of time in which company receives payments from its customers or to convert accounts receivables into cash. A company tries to reduce the days for collection to reduce the cash conversion cycle and we measure this as: ACP $=$ Receivable account * 365 / Sale. Average payment period (APP) describes the number of days it takes the firm to pay off its suppliers. More days for average payment period are preferred to shorten the cash conversion cycle. This measured as: APP = Payable accounts * 365 / Cost of goods sold. Therefore, the Cash Conversion Cycle (CCC) is the time span between the purchase of raw material and the payment against the sale of goods. It is taken as: $\mathrm{CCC}=$ ITID + ACP - APP, shown in equation (2) above.

\section{Dependent Variable}

The dependent variable is firm profitability. The reason for using gross operating profit (GOP) is it excludes the participation of any financial activity from operating activity that might affect overall profitability. Several studies have taken GOP as a proxy for profitability or firm performance and have obtained meaningful results (Raheman and Nasr, 2007; Enqvist, Graham and Nikkinen, 2014). Hence, GOP is measured as: GOP = (Sale- Cost of goods sold) / (Total assets - Financial assets). This measure provides how efficiently the company is managing its operating assets.

\section{Control Variables}

Other than independent variables, there are other factors that affect profitability. If these variables are ignored, then it would confound the results and lead to omitted variable bias. We take Liquidity ratio 
(CR) as a control as it also impacts relationship between current assets and current liabilities. Liquidity shows the short-term financial position of firms. High liquidity contributes to profitability as higher reserves reduce the need for expensive external financing and support operations. The liquidity ratio is taken as: $\mathrm{CR}=$ Current asset / Current liabilities. The Leverage ratio (DR) is taken as another control variable to control for the effects of leverage. Utilization of debt impacts firm profitability and higher debt would result in higher interest payments. Hence, we measure this variable as: DR $=$ Total debt / Total assets. The proxy of Company Size is made through the sales (LOS) variable.

\section{Hypotheses}

We state the hypotheses of this study in alternative form as shown below:

$\mathrm{H}_{1}$ : There is a significant relation in inventory turnover in days and gross operating profitability.

$\mathrm{H}_{2}$ : There is a significant relation in average collection period and gross operating profitability.

$\mathrm{H}_{3}$ : There is a significant relation in average payment period and gross operating profitability.

$\mathrm{H}_{4}$ : There is a significant relation in cash conversion cycle and gross operating profitability.

\section{Model Specifications}

The general regression equation is: $Y=\beta_{0}+\beta_{1} X_{1}+\beta_{2} X_{2}+\beta_{3} X_{3}+\ldots .+\beta_{n} X_{n}+\varepsilon$

The First Model: GOP ${ }_{i t}=\beta_{0}+\beta_{1}\left(\right.$ ITID $\left._{\text {it }}\right)+\beta_{2}\left(\mathrm{CR}_{\text {it }}\right)+\beta_{3}\left(\mathrm{DR}_{\text {it }}\right)+\beta_{4}\left(\mathrm{LOS}_{\text {it }}\right)+\mathrm{v}_{1}$

The Second Model: GOP ${ }_{i t}=a_{0}+a_{1}\left(A C P_{i t}\right)+a_{2}\left(C R_{i t}\right)+a_{3}\left(D_{i t}\right)+a_{4}\left(L_{i t}\right)+v_{2}$

The Third Model: GOP ${ }_{i t}=\gamma_{0}+\gamma_{1}\left(A_{P P} i t\right)+\gamma_{2}\left(C R_{i t}\right)+\gamma_{3}\left(D_{i t}\right)+\gamma_{4}\left(L O S_{i t}\right)+v_{3}$

The Fourth Model: $\mathrm{GOP}_{i t}=\varphi_{0}+\varphi_{1}\left(\mathrm{CCC}_{\mathrm{it}}\right)+\varphi_{2}\left(\mathrm{CR}_{\mathrm{it}}\right)+\varphi_{3}\left(\mathrm{DR}_{\mathrm{it}}\right)+\varphi_{4}\left(\mathrm{LOS}_{\mathrm{it}}\right)+\mathrm{v}_{4}$

Where in each equation:

$\beta_{0,} \mathrm{a}_{0, \gamma}, \varphi_{0}$

$\beta_{1 \ldots} \ldots \beta_{4}, a_{1 \ldots} a_{4}, \gamma_{0} \ldots \gamma_{4}, \varphi_{0} \ldots \varphi_{4}=$ regression model coefficients;

$\varepsilon, \mathrm{v}_{1}, \mathrm{~V}_{1}, \mathrm{v}_{1}, \mathrm{v}_{1}$

$=\quad$ error terms

Subscript it $=\mathrm{i}$ denotes the number of firms; $\mathrm{t}$ indicates the number of years

The variables (along with the abbreviations) are described in Table 3.

\begin{tabular}{ll}
\hline Variables & Formulae \\
\hline Inventory Turnover in Days (ITID) & Inventory *365 / Cost of goods sold \\
Average Collection Period (ACP) & Accounts Receivable *365 / Sales \\
Average Payment Period (APP) & Accounts Payable *365 / Cost of goods sold \\
Cash Conversion Cycle (CCC) & ITID + ACP- APP \\
Gross Operating Profit (GOP) & (Sales- Cost of goods sold) / (Total assets - Financial \\
Liquidity Ratio (CR) & Assets) \\
Leverage Ratio (DR) & Current assets / Current liabilities \\
Company Size (LOS) & Total debt / Total assets \\
& Natural logarithm of sales \\
\hline
\end{tabular}

\section{Results}

Table 3: Variables Description

\section{Descriptive Statistics}

The descriptive statistics for the variables employed in the study are provided in Table 4 . The results indicate that firms are earning on an average 25\% Gross Operating Profit; firms' average inventory conversion period is 85 days; average receivables collection is 55 days and average payment period is 68.5 days. The mean value of cash conversion cycle is 71 days, showing that 71 days is the average time between the cash payments on purchases and cash receipts from sales of goods. The average liquidity ratio of this sector is 1.5 indicating that there are 1.5 times current assets compared to current liabilities. While the debt ratio is high at an average ratio of $56 \%$ and the firm size of 19 log sales. 
Journal of Business and Retail Management Research (JBRMR), Vol. 13 Issue 3

\begin{tabular}{lcccccc}
\hline & Observations & Mean & Std.Dev & Median & Maximum & Minimum \\
\hline GOP & 564 & 25.39211 & 22.35216 & 23.45 & 91.41 & -68.88 \\
ITID & 564 & 84.9019 & 77.79554 & 69.14 & 913.84 & 0.21 \\
ACP & 564 & 55.09477 & 71.06299 & 32 & 580.42 & 0.12 \\
APP & 564 & 68.59163 & 65.00535 & 47.56 & 528.07 & 2 \\
CCC & 564 & 71.40491 & 98.78117 & 59.395 & 804.17 & -278.27 \\
CR & 564 & 1.49952 & 1.078436 & 1.205 & 9.11 & 0.02 \\
DR & 564 & 56.5738 & 20.22806 & 58.4 & 98.31 & 1.52 \\
LOS & 564 & 19.74186 & 2.877313 & 20.42 & 24.54 & 13.25 \\
\hline
\end{tabular}

\section{Correlation Matrix}

Table 4: Descriptive Statistics

The results of the Pearson correlation analysis are presented in Table 5 and the variables have been defined in Table 3 . The findings show that inventory turnover, cash conversion cycle and current ratio are positively associated with gross operating profitability while average collection period, average payment period, debt ratio and size of company are negatively associated with gross operating profitability.

Further, all independent variables are below the $80 \%$ threshold demonstrating that independent variables are not highly associated with each other, with a lesser chance of multicollinearity.

\begin{tabular}{lcccccccc}
\hline & GOP & ITID & ACP & APP & CCC & CR & DR & LOS \\
\hline GOP & 1 & & & & & & & \\
ITID & 0.0568 & 1 & & & & & & \\
ACP & -0.1329 & 0.1629 & 1 & & & & & \\
APP & -0.1334 & 0.2098 & 0.5682 & 1 & & & & \\
CCC & 0.0369 & 0.7667 & 0.4738 & -0.0840 & 1 & & & \\
CR & 0.3014 & 0.1426 & -0.0854 & -0.1829 & 0.1712 & 1 & & \\
DR & -0.256 & -0.0786 & 0.06316 & 0.1082 & -0.0878 & -0.6373 & 1 & \\
LOS & -0.1368 & -0.2232 & -0.1026 & -0.1284 & -0.1651 & -0.3805 & 0.2442 & 1 \\
\hline
\end{tabular}

Table 5: Correlation Matrix

Results of Multicollinearity

\begin{tabular}{|c|c|c|c|c|c|c|c|}
\hline \multicolumn{8}{|c|}{ Variance Inflation Factor $<10$} \\
\hline & ITID & $A C P$ & $A P P$ & $\mathrm{CCC}$ & $C R$ & $D R$ & LOS \\
\hline ITID & 1 & & & & & & \\
\hline $\mathrm{ACP}$ & 1.027289 & 1 & & & & & \\
\hline APP & 1.046045 & 1.476933 & 1 & & & & \\
\hline $\mathrm{CCC}$ & 2.426518 & 1.289468 & 1.007112 & 1 & & & \\
\hline $\mathrm{CR}$ & 1.020778 & 1.007377 & 1.034631 & 1.030193 & 1 & & \\
\hline $\mathrm{DR}$ & 1.006231 & 1.004006 & 1.011866 & 1.007768 & 1.683996 & 1 & \\
\hline LOS & 1.052418 & 1.010654 & 1.016762 & 1.028032 & 1.169316 & 1.063478 & 1 \\
\hline
\end{tabular}

Table 6: Tests of Multicollinearity

The variance inflation factors shown in Table 6 for all the independent variables are less than 10 . This indicates that our regression models do not suffer from any problems of Multicollinearity and that the independent variables are not correlated.

Results of Autocorrelation.

\begin{tabular}{cc}
\hline Models & Durbin Watson Value $>\mathbf{=} \mathbf{2}$ \\
\hline Model 1 (ITID) & 2.086794 \\
Model 2 (ACP) & 2.072237 \\
Model 3 (APP) & 2.074625 \\
Model 4 (CCC) & 2.07807 \\
\hline
\end{tabular}

Table 7: Autocorrelation

www.jbrmr.com A Journal of the Academy of Business and Retail Management (ABRM) 
Durbin Watson statistics shown in Table 7 for all models is close to 2.0 indicating that there are no problems of autocorrelation in the residuals of the models.

\section{Results of Hausman test}

Subsequently we perform the Hausman Test to determine whether the fixed or random is a more appropriate model to use for our analysis. The results of Hausman test are shown in Table 8. The null hypothesis of the test is that both the parameter estimates are valid, while the alternative hypothesis states that the fixed effects model is the correct model of choice. The $p$ values of all the models are $<0.05$, indicating that we reject the null hypothesis and accept the alternative hypothesis and therefore we choose the fixed effects regression methodology for our analysis.

\begin{tabular}{lccc}
\hline \multicolumn{4}{c}{ Correlated Random Effects - Hausman Test } \\
\hline & Chi-Sq.Statistic & Chi-Sq.d.f. & Prob. \\
\hline Model 1 (ITID) & 12.29952 & 4 & $0.0153<0.05$ \\
Model 2 (ACP) & 11.61242 & 4 & $0.0205<0.05$ \\
Model 3 (APP) & 11.09351 & 4 & $0.0255<0.05$ \\
Model 4 (CCC) & 11.44998 & 4 & $0.0219<0.05$ \\
\hline
\end{tabular}

Table 8: Hausman Test for all Models

\section{Results of Fixed Effects Models}

Table 9 presents results of all four regression models using the fixed effects methodology. All four models take gross operating profit as the dependent variable with Models 1, 2, 3 and 4 taking inventory turnover, average collection period, average payables period and cash conversion cycle as explanatory variables in each model respectively. The control variables are liquidity ratio, leverage ratio and firm size.

\begin{tabular}{|c|c|c|c|c|}
\hline Parameter & $\begin{array}{l}\text { Model } 1 \\
\text { (IIID) }\end{array}$ & $\begin{array}{l}\text { Model } 2 \\
\text { (ACP) }\end{array}$ & $\begin{array}{l}\text { Model } 3 \\
\text { (APP) }\end{array}$ & $\begin{array}{l}\text { Model } 4 \\
\text { (CCC) }\end{array}$ \\
\hline $\mathbf{R}^{2}$ & 0.553603 & 0.55306 & 0.556492 & 0.552724 \\
\hline Adjusted $\mathrm{I}^{2}$ & 0.460684 & 0.460027 & 0.464173 & 0.459621 \\
\hline F-statistics & 5.957883 & 5.944792 & 6.027966 & 5.93672 \\
\hline Prob(F) & 0.000000 & 0.000000 & 0.000000 & 0.000000 \\
\hline Significance & -1.3282 & -1.30324 & -1.24952 & -1.39025 \\
\hline Constant & -37.151 & -36.7235 & -34.8534 & -38.9929 \\
\hline$\underset{\text { (p.val) }}{\text { IID }}$ & $\begin{array}{r}-0.01384 \\
(0.3384)\end{array}$ & & & \\
\hline$\underset{\text { (p-val) }}{A C P}$ & & $\begin{array}{r}-0.01205 \\
(0.5542)\end{array}$ & & \\
\hline$\underset{\text { (p-val) }}{\text { APP }}$ & & & $\begin{array}{l}-0.0407 \\
(0.0472)\end{array}$ & \\
\hline$\underset{\text { (p-val) }}{c \subset c}$ & & & & $\begin{array}{l}0.000158 \\
(0.9892)\end{array}$ \\
\hline$\underset{\text { (p-val) }}{\text { CR }}$ & $\begin{array}{c}1.030935 \\
(0.5369)\end{array}$ & $\begin{array}{c}0.926182 \\
(0.579)\end{array}$ & $\begin{array}{l}0.842688 \\
(0.6123)\end{array}$ & $\begin{array}{c}0.951058 \\
(0.5692)\end{array}$ \\
\hline$\underset{\text { (p-val) }}{\text { DR }}$ & $\begin{array}{l}-0.10931 \\
(0.2151)\end{array}$ & $\begin{array}{c}-0.11084 \\
(0.209)\end{array}$ & $\begin{array}{l}-0.10989 \\
(0.2109)\end{array}$ & $\begin{array}{c}-0.11291 \\
(0.201)\end{array}$ \\
\hline $\begin{array}{l}\text { Los } \\
\text { (p-val) }\end{array}$ & $\begin{array}{c}3.462516 \\
(0.014)\end{array}$ & $\begin{array}{c}3.427294 \\
(0.0155)\end{array}$ & $\begin{array}{c}3.443992 \\
(0.0141)\end{array}$ & $\begin{array}{c}3.512099 \\
(0.0129)\end{array}$ \\
\hline
\end{tabular}

Table 9: Fixed effects models

Inventory turnover in days has $\mathrm{p}$-value $=0.3384>0.05$ which indicates insignificant relation with gross operating profit. Average collection period has $p$-value $=0.5542>0.05$ which specifies insignificant relation with gross operating profit. Average payment period has $\mathrm{p}$-value $=0.0472<0.05$ which directs significant relation with gross operating profit. Cash conversion cycle has $p$-value $=0.9892>0.05$ which shows insignificant relation with gross operating profit. 


\section{Discussion and Conclusion Discussion}

Model 1, Impact of Inventory Turnover in Days on Profitability: The insignificant relationship of inventory turnover in days shows that an increase or decrease in inventory has no impact on profitability and therefore, we reject the first hypothesis $\mathrm{H}_{1}$. The findings are consistent with Lazaridis and Tryfonidis (2006); Falope and Ajilore (2009); Mansoor and Muhammad (2012); Raheman and Nasr (2007); Dong (2010); Deloof (2003) and $\mathrm{Lu}$ (2013) to suggest that there is no impact of inventory turnover on gross profitability.

Model 2, Impact of Average Collection Period on Profitability: Average collection period has insignificant results which indicate that the increase or decrease in collection period has no impact on profitability and therefore our results do not find any support for the second hypothesis $\mathrm{H}_{2}$. These results are consistent with the findings of Mathuva (2010), Lazaridis and Tryfonidis, 2006, Mansoor and Muhammad (2012), Raheman and Nasr (2007), and Dong (2010) who also do not find any significant association between average collection period and firm profitability.

Model 3, Impact of Average Payment Period on Profitability: Negative relation between average payment period and profitability means increase in payment period has a negative impact on profitability. Significant relationship indicates that the payment period has an impact on profitability and the results support the third hypothesis $\mathrm{H}_{3}$. These results find support in the literature (Raheman and Nasr, 2007; Saghir, 2011; Hashmi and Hussain, 2011; Raheman, Afza, Qayyum and Bodla, 2010; Deloof, 2003).

Model 4, Impact of Cash Conversion Cycle on Profitability: Therefore, the results do not support the fourth hypothesis $\mathrm{H}_{4}$ to show that there is no association between cash conversion cycle and firm profitability in our sample of firms. Gill (2012), Biger and Mathur (2012) and Lyroudi and Lazaridis (2000) obtain similar results.

Model 5, Impact of Control Variables on Profitability: Current ratio, leverage ratio and size of firm are the control variables of the study. Results show a positive relationship of current ratio and firm size with profits, while debt ratio has negative relationship with gross operating profitability. However, only firm size shows a strong significant impact on firm profitability.

The results are mixed and indicate both significant and insignificant relationship of independent variables with profitability. It means firms are not managing their working capital efficiently. The mixed results find support in other studies conducted on Pakistan, as shown in the previous section. The reason for the results could be that in developing economies capital is constrained and more attention is given towards the growth and efficiency of fixed capital while management of working capital is largely neglected. This is the reason why Pakistani firms are facing problems arising from mismanagement of resources. Therefore, to avoid such type of results firms should properly manage short term working capital along with the monitoring of fixed capital.

\section{Conclusion}

Working capital is an important resource available to organizations and if managed efficiently provides for the smooth running of operations and enhanced profitability. Since the last few years the manufacturing sector of Pakistan is growing and continuously moving towards innovation and progress. With the advent of the CPEC initiative it has become imperative that companies utilize all their resources optimally to stay competitive in this environment. Proper management of working capital provides cost savings and increased profits for the firm.

Using a data sample comprising 94 non-financial firms listed on PSE for the period from 2011 2016, we investigate effectiveness of the current working capital practices in Pakistan. The insignificant results of fixed effects models suggest that inventory turnover, average collection period and cash conversion cycle as components of the working capital management do not impact firm profitability. However, average payment period is the only factor having significant negative relationship with profitability demonstrating that shorter payment periods result in enhanced profits.

The findings indicate that the manufacturing sector in Pakistan may be concentrating on the current liabilities side of the working capital equation for enhancing profits. The descriptive statistics highlight 
that firms in the sample are relying heavily on leverage with $56 \%$ debt ratio and maintaining a 1.5 current ratio. The ratios would therefore suggest that a higher level of current assets or liquidity is being maintained by the manufacturing sector, to support a higher level of borrowings. Ample reserves of inventories, receivables and cash are being maintained possibly as a cushion against both financial and operational risks and current assets are not being managed to achieve optimal levels of working capital. In this environment, faster payments to suppliers seem to enhance profitability and have no adverse impact on liquid assets.

The results could indicate the inefficient deployment of resources in developing countries such as Pakistan, where management lacks the expertise to optimally allocate capital between fixed capital and working capital, and properly manage working capital. However, in this study we do not find negative impacts of current asset management on profitability but find insignificant impact on profitability. We conclude that cash conversion cycle may not be an important factor in this sector and levels of current asset may be maintained for other reasons, other than working capital requirements. It appears that manufacturing firms are more focused on managing current payables for the cost savings it provides through trade and cash discounts that enhances profitability. It also suggests that as manufacturing firms are involved in high levels of borrowings, the maintaining of efficient liquidity ratios may be more important to fulfill lenders requirements, rather than maintain optimal working capital and may provide more financial benefits in this sector. Further implications of the study are that the firm's working capital and long-term financing/capital strategies, policies and practices need to be examined simultaneously.

\section{Limitations and Future Directions}

The study has certain limitations. Firstly, the sample is limited to Pakistani non-financial firms. Further the top five companies of each sector are taken according to their revenue which then captures working capital practices of the larger tier manufacturing companies. Another limitation is availability of data and all those companies are excluded that had missing financial data for the 6 years from 2011-2016.

There is potential for future research in this area. The findings suggest that management may be considering short term and long-term capital/financing strategies together. As such there may be a substitutive (or complementary) effect which needs to be considered in future research using structural equations model or simultaneous equations model to overcome problems of endogeneity that may exist. Further it is suggested that working capital components may be examined individually to assess their impacts on firm risk, borrowings and the liquidity practices.

\section{References}

Brigham, E., \& Ehrhardt, M., 2002, 'Financial management theory and practice', tenth edition, Thomson Learning, SouthWestern, 5191 Natorp Boulevard, Mason, Ohio 45040, USA.

Deloof, M., 2003, 'Does working capital management affect profitability of Belgian firms?',Journal of Business Finance $\mathcal{E}$ Accounting, 573-588.

Ding, S., Guariglia, A. \& Knight, J., 2013,'Investment and financing constraints in China: Does

working capital management make a difference?', Journal of Banking \& Finance, 1490-1507.

Enqvist, J., Graham, M.\& Nikkinen, J., 2014,'The impact of working capital management on firm profitability in different business cycles: Evidence from Finland', Research in International Business and Finance, 36-49.

Falope, O. I. \& Ajilore O. T., 2009,'Working capital management and corporate profitability: evidence from panel data analysis of selected quoted companies in Nigeria', Reasearch Journal of Business Management, 73-84.

Gill, A., Biger, N. \& Mathur, N., 2010,'The relationship between working capital management and corporate profitability: evidence from the United States',Business and Economics Journal, 1-9.

Gill, S.A. \& Biger, N., 2013, 'The impact of corporate governance on working capital management effeciency of American manufacturing firms',Mangerial Finance, 116-132.

Gracia-Teruel, J. P. \& Martinez-Solano, P., 2007,'Effects of working capital management on SME profitability',International Journal of Managerial Finance, 164-177.

Jose, M. L., Lancaster, C.\& Stevens, J.L., 1996, 'Corporate returns and cash conversion cycle', Journal of Economics and Finance, 33-46.

Kumaraswamy, S., 2016,'Impact of working capital mangement on financial performance of Gulf cooperation council firms', International Journal of Economics and Financial Issues, 1136-1142. 
Lazaridis, I. \& Tryfonidis, D., 2006,'Relationship between working capital management and profitability of listed companies in the Athens stock exchange', Journal of Financial Management and Analysis, 26-35.

Mansoor, E. \& Dr. Muhammad., 2012, 'The effect of working capital management on firm's profitability: evidence from Singapore', Interdisciplinary Journal of Contemporary Research in Business, 472-486.

Marttonen, S., Monto, S.\& Karri, T., 2013,'Profitable working capital management in industrial maintenance companies'. Journal of Quality in Maintenance Engineering, 429-448.

Mathuva, M . D., 2010,'The influence of working capiatl management components on corporate profitability: A survey on Kenyan listed firms', Research Journal of Business Management, 1-11.

Nasreen, S., Khanam, F.\& Pirzada, S. S., 2014,'Impact of working capital mangement on firm's profitability,Research Journal of Finance and Accounting,2222-2847.

Orobia, A. L., Byabashaija, W., Munene, C. J., Sejjaaka, K. S.\& Musinguzi, D., 2007,'How do small business owners manage working capital in an emerging economy?',Qualitative Research in Accounting \& Management, $164-177$.

Ponsian, N., Chrispina, K., Tago, G.\& Mkiibi, H., 2014,'The effect of working capital mangement on profitability',International Journal of Economics, Finance and Management Sciences, 347-355.

Padachi, K., 2006,'Trends in working capital management and its impact on firms' performance: An analysis of Mauritian small manufacturing firms',International Review of Business Research Papers, 45-58.

Pais, A. M.\& Gama, M. P., 2015,'Working capital management and SMEs profitability: Portuguese evidence'. International Journal of Managerial Finance, 341-358.

Raheman, A.\& Nasr, M., 2007,'Working capital management and profitability-Case of Pakistani firms', International Review of Business Research Papers, 279-300.

Raheman, A., Afza, T., Qayyum, A.\& Bodla, A. M., 2010,'Working capital management and corporate performance of manufacturing sector in Pakistan',International Research Journal of Finance and Economics.

Raza, Y. M., Bashir, M., Latif, K., Shah, S. T.\& Ahmad, M., 2015,'Impact of working capital mangement on profitability: evidence from Pakistan oil sector',International Journal of Accounting and Financial Reporting, 21623082.

Saghir, A., Hashmi, M. F.\& Hussain, N. M., 2011,'Working capital management and profitability: Evidence from Pakistan firms',Journal of Contemporary Research in Business, Vol. 3, No. 8.

Sharma, K. A.\& Kumar, S., 2011,'Effect of Working Capital Management on Firm Profitability: empirical Evidence from India',Global Business Review, 159-173.

Shin, H-H.\& Soenen, L., 1998,'Effeciency of working capital management and corporate profitability',Financial Practice and Education, 37-45.

Singh, P.H. \& Kumar, S., 2014,'Working capital management: a literature review and research agenda',Quality Research in Financial Markets, 173-197.

Wasiuzzaman, S., 2015,'Working capital and firm value in an emerging market',International Journal of Managerial Finance, 60-79.

Appendix 1

List of Sectors and Companies in Sample

\begin{tabular}{|c|c|c|}
\hline SECTORS & \multicolumn{2}{|l|}{ TOP 5 COMPANIES } \\
\hline \multirow{6}{*}{ 1-AUTOMOBILE ASSEMBLER } & COMPANIES & REVENUE OF 2016 \\
\hline & 1-Sazgar Engineering Works Limited & $2,473,657,974$ \\
\hline & 2-Ghani Automobile Industries Limited & $126,664,437$ \\
\hline & 3-Indus Motor Company Limited & $96,516,322$ \\
\hline & 4-Pak Suzuki Motor Company Limited & $84,548,757$ \\
\hline & 5-Atlas Honda Limited & $45,772,177$ \\
\hline \multirow{5}{*}{ 2-AUTOMOBILE PARTS AND ACCESSORIES } & 1-Thal Limited & $18,938,928$ \\
\hline & 2-Atlas Battery Limited & $15,961,413$ \\
\hline & 3-General Tyre and Rubber Co. of Pakistan Limited & $9,491,652$ \\
\hline & 4-Agriautos Industries Limited & $4,923,276$ \\
\hline & 5-Baluchistan Wheels Limited & $1,378,332$ \\
\hline \multirow{4}{*}{ 3-CABLE \& ELECTRICAL GOODS } & 1-TPL Trakker Limited & $1,457,620,441$ \\
\hline & 2-Pak Elektron Limited & $25,122,267$ \\
\hline & 3-Siemens Pakistan Engineering Co. Limited & $9,266,909$ \\
\hline & 4-Pakistan Cables Limited & $6,956,670$ \\
\hline
\end{tabular}

www.jbrmr.com A Journal of the Academy of Business and Retail Management (ABRM) 


\begin{tabular}{|c|c|c|}
\hline & 5-Singer Pakistan Limited & $1,574,371$ \\
\hline \multirow{5}{*}{ 4-CEMENT } & 1-Kohat Cement Limited & $12,472,196,679$ \\
\hline & 2-Pakcem Limited & $5,588,436,730$ \\
\hline & 3-Flying Cement Company Limited & $2,222,797,816$ \\
\hline & 4-Dandot Cement Company Limited & $2,138,894,941$ \\
\hline & 5-Safe Mix Concrete Limited & $690,183,505$ \\
\hline \multirow{5}{*}{ 5-CHEMICAL } & 1-Sitara Chemical Industries Limited & $8,722,879,814$ \\
\hline & 2-Nimir Industrial Chemicals Limited & $3,663,499,323$ \\
\hline & 3-Agritech Limited & $3,542,570,270$ \\
\hline & 4-Dynea Pakistan Limited & $2,387,735,723$ \\
\hline & 5-Nimir Resins Limited & $1,806,427,261$ \\
\hline \multirow{5}{*}{ 6-ENGINEERING } & 1-Amreli Steels Ltd & $14,413,661,405$ \\
\hline & 2-mughal steel $n$ iron & $12,241,271,852$ \\
\hline & 3-Bolan Casting Limited & $1,695,718,102$ \\
\hline & 4-Ados Pakistan Limited & $580,257,047$ \\
\hline & 5-International Steels Limited & $17,938,077$ \\
\hline \multirow{3}{*}{ 7-FERTILIZER } & 1-Engro Fertilizers Limited & $87,615,258$ \\
\hline & 2-Fauji Fertilizer Company Limited & $84,831,024$ \\
\hline & 3-Fauji Fertilizer Bin Qasim Limited & $52,182,072$ \\
\hline \multirow{5}{*}{ 8-FOOD AND PERSONAL CARE PRODUCTS } & 1-Fauji Foods Limited & $18,666,018,730$ \\
\hline & 2-Ismail Industries Limited & $14,317,046,845$ \\
\hline & 3-Mitchells Fruit Farms Limited & $1,696,332,638$ \\
\hline & 4-Shield Corporation Limited & $1,248,961,378$ \\
\hline & 5-Quice Food Limited & $209,615,825$ \\
\hline \multirow{5}{*}{ 9-GLASS N CERAMICS } & 1-Ghani Glass Limited & $11,260,189,883$ \\
\hline & 2-Tariq Glass Industries Limited & $8,040,166,922$ \\
\hline & 3-Karam Ceramics Limited & $1,304,166,041$ \\
\hline & 4-Emco Industries Limited & $782,866,717$ \\
\hline & 5-Ghani Value Glass Limited & $670,192,009$ \\
\hline \multirow{2}{*}{ 10-LEATHER N TANNERIES } & 1-Service Industries Limited & $17,544,736$ \\
\hline & 2-Bata Pakistan Limited & $14,781,520$ \\
\hline \multirow{5}{*}{ 11-OIL \& GAS MARKETING COMPANIES } & 1-Pakistan State Oil Company Limited & $913,094,377$ \\
\hline & 2-Shell Pakistan Limited & $197,128,351$ \\
\hline & 3-Sui Northern Gas Pipelines Limited & $212,520,573$ \\
\hline & 4-Attock Petroleum Limited & $205,715,461$ \\
\hline & 5-Sui Southern Gas Company Limited & $158,853,447$ \\
\hline \multirow{5}{*}{ 12-PAPER \& BOARD } & 1-Merit Packaging Limited & $2,023,248,518$ \\
\hline & 2-Pakistan Paper Products Limited & $576,333,215$ \\
\hline & 3-Packages Limited & $16,024,977$ \\
\hline & 4-Century Paper and Board Mills Limited & $13,186,182$ \\
\hline & 5-Cherat Packaging Limited & $6,223,832$ \\
\hline \multirow{5}{*}{ 13-PHARMACEUTICALS } & 1-Highnoon Laboratories Limited & $4,403,995,318$ \\
\hline & 2-GlaxoSmithKline (Pakistan) Limited & $23,821,926$ \\
\hline & 3-Abbot Laboatories & $21,170,446$ \\
\hline & 4-Sanofi-Aventis Pakistan Limited & $10,785,879$ \\
\hline & 5-Wyeth Pakistan Limited & $2,674,709$ \\
\hline \multirow{4}{*}{ 14-POWER GENERATION \& DISTRIBUTION } & 1-Nishat Chunian Power Limited & $22,574,562,189$ \\
\hline & 2-Sitara Energy Limited & $3,658,738,922$ \\
\hline & 3-Hub Power Company Limited & $131,483,801$ \\
\hline & 4-Nishat Power Limited & $22,313,634$ \\
\hline
\end{tabular}




\begin{tabular}{|c|c|c|}
\hline \multirow{3}{*}{ 15-REFINERY } & 1-National Refinery Limited & $148,456,509$ \\
\hline & 2-Byco Petroleum Pakistan Limited & $94,807,329$ \\
\hline & 3-Pakistan Refinery Limited & $91,174,700$ \\
\hline \multirow{5}{*}{ 16-SUGAR N ALLIED INDUSTRY } & 1-J.D.W. Sugar Mills Limited & $32,663,442,974$ \\
\hline & 2-Thal Industries Corporation Limited & $11,244,798,613$ \\
\hline & 3-Dewan Sugar Mills Limited & $4,442,366,162$ \\
\hline & 4-Mehran Sugar Mills Limited & $4,361,359,652$ \\
\hline & 5-Faran Sugar Mills Limited & $3,084,634,409$ \\
\hline \multirow{4}{*}{ 17-SYNTHETIC RYON } & 1-Al-Abid Silk Mills Limited & $246,638,730$ \\
\hline & 2-Gatron Industries Limited & $10,275,281$ \\
\hline & 3-Rupali Polyester Limited & $4,841,940$ \\
\hline & 4-Pakistan Synthetics Limited & $1,543,633$ \\
\hline \multirow{5}{*}{ 18-TEXTILE COMPOSITE } & 1-Nishat Chunian Limited & $23,780,454,796$ \\
\hline & 2-Sapphire Textile Mills Limited & $23,315,336,620$ \\
\hline & 3-Sapphire Fibers Limited & $13,347,275,852$ \\
\hline & 4-Reliance Weaving Mills Limited & $10,878,061,963$ \\
\hline & 5-Azgard Nine Limited & $10,701,888,196$ \\
\hline \multirow{5}{*}{ 19-TEXTILE SPINNING } & 1-Din Textile Mills Limited & $8,552,540,730$ \\
\hline & 2-Kohinoor Spinning Mills Limited & $7,906,020,841$ \\
\hline & 3-Nadeem Textile Mills Limited & $5,224,533,979$ \\
\hline & 4-Tata Textile Mills Limited & $5,066,353,330$ \\
\hline & 5-Ellcot Spinning Mills Limited & $4,588,787,945$ \\
\hline \multirow{3}{*}{ 20-TEXTILE WEAVING } & 1-Prosperity Weaving Mills Limited & $5,811,481,540$ \\
\hline & 2-Shahtaj Textile Mills Limited & $3,291,892,388$ \\
\hline & 3-I.C.C. Textile Limited & $540,947,637$ \\
\hline \multirow{3}{*}{ 21-ТОВВАСО } & 1-Khyber Tobacco Company Limited & $882,717,081$ \\
\hline & 2-Pakistan Tobacco Company Limited & $42,907,191$ \\
\hline & 3-Philip Morris (Pakistan) Limited & $14,416,905$ \\
\hline 22-VANASPATI AND ALLIED INDUSTRY & 1-Punjab oil mills & $4,251,242,055$ \\
\hline 23-WOLLEN & 1-Bannu Woollen Mills Limited & 796,977 \\
\hline
\end{tabular}

